\title{
Article
}

\section{Mass of the Vermiform Appendix in Bangladeshi People}

\author{
Rahman MM¹, Khalil $\mathbf{M}^{2}$, Khalil $\mathbf{M}^{3}$, Jahan $\mathrm{KM}^{4}$, Shafiquazzaman $\mathbf{M}^{5}$, Parvin $\mathbf{B}^{6}$
}

This study was done to measure the weight of vermiform appendix in Bangladeshi people to augment the data regarding variational anatomy in our setting. A total 100 vermiform appendix (male -60 , female - 40) were excised from cadaver of different age and sex during routine post mortem examination in the autopsy laboratory of Forensic Medicine Department of Mymensingh Medical College. This cross-sectional study was done by convenient sampling technique. The weight depended on length and thickness. The weight decreases gradually with advancing age probably decreasing number of lymphatic follicle and that replaced by connective tissue. Lymphatic follicles were examined and estimated by microscope. For convenience of differentiating the weight of vermiform appendix in relation to age and sex, specimens were categorized in four age groups (up to 20 year, 21 - 35 years, 36 - 55 years, $56-70$ years). Mean weight of vermiform appendix was maximum in group - B (4.07 $\pm \mathrm{SE} 0.82 \mathrm{gm})$ and minimum in group $\mathrm{D}(3.01 \pm \mathrm{SE} 0.74 \mathrm{gm})$. The weight range was from $2 \mathrm{gm}$ (group - D) to 5.50 gm (group - B). Diameter of lymphatic follicle was largest 43.08 micrometer in group-A, and least diameter was 3.08 micrometer in group - $\mathrm{D}$. The range of number of lymphatic follicle was 1 to 6 . Mean number of lymphatic follicle in male was 4.48 \& in female were 5.40.

Key Words: Human Vermiform, Appendix, Weight, Lymphatic, Follicle

J Bangladesh Soc Physiol.2008 Dec;(3):8-12. For author affiliations, see end of text. http://www.banglajol.info/index.php/JBSP

\section{Introduction}

$\Gamma$ he appendix is vascular, rich in lymphoid follicle \& produces immune system cells normally involved with the gut associated lymphoid tissue \& this organ lies in the junction between small \& large gut. Vital function of lymphoid tissue in vermiform appendix is gut immunity. It causes the mucosal folds of vermiform appendix and irregularity of its lumen ${ }^{1}$. In young age weight remain almost same up to 40 years then gradually decrease the weight. The lumen of vermiform appendix is almost fibrosed due to scarring of fibrous tissue, by replacing the lymphoid follicle.

In 15.5 weeks of gestation lymphoid follicle first appears in the vermiform appendix. External diameter, luminal diameter, lymphatic follicle \& germinal centre are more in young than old age 2 . In old age lumen is almost fibrosed and lymphatic follicles are replaced by fibrous tissue \& weights of vermiform appendix are also decrease. Gradually decrease number of lymphoid follicle causes to decrease the weight of vermiform appendix \& that decreases the gut immunity. So variation of weight of vermiform appendix is one of the important factors related to gut immunity.

\section{Methods}

To perform this study, one hundred normal vermiform appendixes of both sexes were collected from dead bodies during routine postmortem examination due to accidental and unnatural death from the morgue of Forensic

J Bangladesh Soc Physiol. 2008 Dec;(3):8-12. 
Medicine Department of Mymensingh Medical College. Abdomen was opened by classical midline incision \& then another incision was given in the right paracolic gutter, caecum with appendix were excised by giving ligature. After placing the specimen in the basin, the ligatures were opened \& wash out by running tap water. Then the appendix was excised at the base \& the meso appendix was also excised \& its contents were removed by milking. Weight of vermiform appendix was measured by table scientific balance in grams \& recorded in a prepared format. Vermiform appendix of the decomposed bodies, poisonous cases \& lacerated injured cases in the caecum or near the vermiform appendix were excluded.

For histological study, about 3 - 6 mm size transverse section from mid portion of the appendix was taken \& processed by routine haematoxylin \& eosin stain \& also by special periodic-acid-schiff \& verhoeffs stain. 10 slides from each group of both sexes were examined for histological study.

Estimation of number of lymphoid follicles for each vermiform appendix was done by the following procedure:

10 slides were selected from each group. For the determination of the number of lymphoid follicles, the entire section of each slide was focused under low magnification (10x) with light microscopic by giving marked point in the focused slide above (12-o'clock) and below (6o'clock) and right (3-o’clock) to left (9-o’clock) to avoid repeat counting. The total number of lymphoid follicles in each section under 4 focus area were observed. Under each focus area all lymphatic follicles even a portion of lymphatic follicle was included and their total no was counted. From these, the mean number of lymphoid follicles per group was calculated and recorded in a prepared format.

The cadaver ages were up to 70 years. For convenience of differentiating the changes regarding number of lymphatic follicle as well as weight of vermiform appendix in relation to age, collected specimens were grouped in group A (up to 20 years), group B (21 - 35 years), group C (36 - 55 years) \& group D ( 56 - 70 years).

\section{Results}

Weights of vermiform appendix in different age groups were expressed in grams and results are shown in Table-I.

In group A: range of weight of vermiform appendix, in male, was $2.00-4.20$ grams and in female was 2.9 - 5.00 grams. In group B: range of weight of vermiform appendix, in male, was 2.00 - 5.50 grams and in female was $3.00-$ 4.90 grams. In group C: range of weight of vermiform appendix in male was 2.40 to 4.00 grams and in female were $2.10-5.00 \mathrm{gms}$. In group D: range of weight of vermiform appendix in male was 2.10 - 5.00 grams and in female were $2.00-4.00 \mathrm{gms}$. In this study, the ranges of weight of vermiform appendix of group A and group $B$ were in wider than that of group C \& D in male.

In respect to mean: In group- $\mathrm{A}$, mean $\pm \mathrm{SE}$ weight were $3.05 \pm 0.65$ gm in male $\& 3.77 \pm 0.73$ $\mathrm{gm}$ in female. Again in group $\mathrm{B}$, mean $\pm \mathrm{SE}$ weight were $3.97 \pm 0.72 \mathrm{gm}$ in male \& 3.01 \pm 0.41 gm in female. Similarly, in group $\mathrm{C}$ mean were $3.41 \pm 0.73$ in male \& $3.01 \pm 0.41$ in female. In group $\mathrm{D}$, mean was $3.06 \pm 0.88 \mathrm{gm}$ in male and $3.08 \pm 0.74 \mathrm{gm}$ in female. Here mean weight of group $\mathrm{B}$ was more than other groups.

In respect to sex: Weight of female vermiform appendix was more than male except in group $\mathrm{C}$ \& D. In group $\mathrm{D}$, mean weight of vermiform appendix were lowest in both male and female among the four groups. Here group B had highest weight and group D had lowest weight. So, with advancing age that is after third decade of life gradually decrease the weight of vermiform appendix.

\section{Lymphatic follicle}

Results are presented in figure 1

In group $A$ : the range of number of lymphatic follicle was $3.20-6.00$ in male and in female it 
Article

Mass of vermiform appendix

Table I: Weight of vermiform appendix in different age groups

\begin{tabular}{lcccccc}
\hline Age & $\begin{array}{c}\text { Number of } \\
\text { observation } \\
(\mathrm{n})\end{array}$ & $\begin{array}{c}\text { Male } \\
\text { Mean } \pm \text { SE } \\
(\mathrm{gm})\end{array}$ & $\begin{array}{c}\text { Number of } \\
\text { observation } \\
(\mathrm{n})\end{array}$ & $\begin{array}{c}\text { Female } \\
\text { Mean } \pm \mathrm{SE} \\
(\mathrm{gm})\end{array}$ & $\begin{array}{c}\text { Male } \\
\text { Mean } \pm \text { SE } \\
\text { (range) }\end{array}$ & $\begin{array}{c}\text { Female } \\
\text { Mean } \pm \text { SE } \\
\text { (range) }\end{array}$ \\
\hline A (up to 20 years ) & 13 & $3.05 \pm 0.65$ & 15 & $3.77 \pm 0.73$ & $2.00-4.20$ & $2.9-5.00$ \\
B (21 to 35 years) & 28 & $3.97 \pm 0.82$ & 11 & $4.07 \pm 0.56$ & $2.00-5.50$ & $3.00-4.90$ \\
C (36 to 50 years) & 10 & $3.41 \pm 0.73$ & 8 & $3.08 \pm 0.91$ & $2.40-4.00$ & $2.10-5.00$ \\
D (51 to 70 years) & 9 & $3.06 \pm 0.88$ & 6 & $3.01 \pm 0.74$ & $2.10-5.00$ & $2.00-4.00$ \\
Mean & & 3.49 & & 3.48 & & \\
\hline
\end{tabular}

' $\mathrm{n}$ ' represents the number of specimens examined in each group

The differences of weight between group B and A was moderately significant. Although differences of weight between C \& group D were significant but differences between groups B \& D was highly statistically significant.

was 1.00 - 3.00. In group B: the range of number of lymphatic follicle was $3.00-5.40$ in male and in female it was 2.20 - 3.60. In group C: the range of number of lymphatic follicle was $3.00-3.60$ in male and in female it was $2.00-3.00$. In group D: the range of number of lymphatic follicle was 0.00 -1.80 in male and in female it was $0.00-0.60$.

In respect to mean: In male, group $\mathrm{A}$, mean $\pm \mathrm{SE}$ was $4.48 \pm 1.25 \&$ in female, was $5.40 \pm 1.30$.

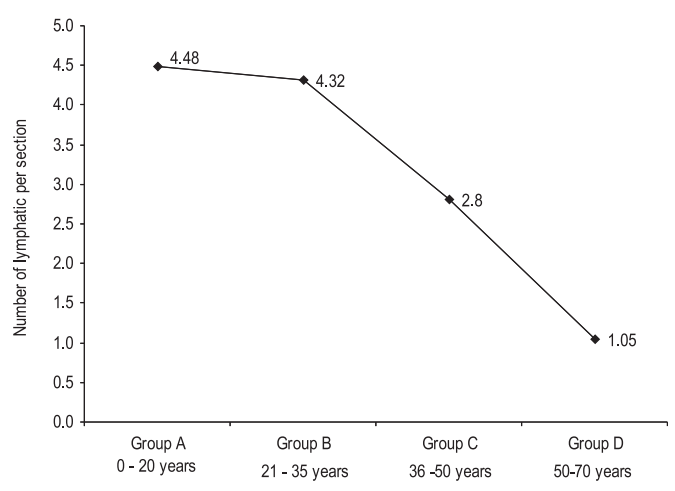

Figure 1. Showing mean the number of lymphoid follicles per section in different age groups

In male group B, Mean was $4.32 \pm \mathrm{SE} 0.41$ \& in female, Mean was 3. $4 \pm$ SE 0.54 .

In male group C, Mean was $2.80 \pm \mathrm{SE} 0.58 \&$ in female, Mean was $2.76 \pm S E 0.43$. In male group
D, Mean was $1.05 \pm$ SE 0.35 \& in female Mean was $0.24 \pm \mathrm{SE} 0.33$. Number of lymphatic follicle of vermiform appendix in group A was more in female than male. Number of lymphatic follicle of group A was more than other groups.

In the above, groups showed that the number of follicles gradually decreasing with advancing age that is after third decade of life as lymphatic follicles were replaced by connective tissue.

\section{Discussion}

The present study was performed on 100 human vermiform appendixes in both sexes of Bangladeshi people up to 70 years age. All these specimens were studied gross \& histomorphometrically. The mucosa and part of submucosa was replaced by fibrous connective tissue and gradual decrease of lymphatic follicle were observed after middle age. After the age of 60 , virtually no lymphoid tissue remains within the appendix and complete obliteration of the lumen of the appendix is common. ${ }^{3}$ The submucosa contains numerous lymphatic follicle or aggregations. These lymphoid tissues have prompted the concept that the appendix is the human equivalent of the avian or of Fabricius as site of maturation of thymus - independent lymphocytes. While no discernible change in immune function results from appendectomy, the prominence of lymphatic tissue in the appendix 
of young adults seems important in the etiology of appendicitis ${ }^{4}$.

The lymphoid follicle after appearing in the appendix remains steady for the next two decade and begins to decrease with increasing the age. Its epithelium lining has a surface coat of immunoglobulin which may be involved in the control of lymphatic surveillance ${ }^{4}$.

The appendix in youth is characterized by a large concentration of lymphoid follicles that appear two weeks after birth and number about 20 or more at age 15 . There after progressive atrophy of lymphoid tissue proceeds concomitantly with fibrosis of the wall and partial or total obliteration of the lumen ${ }^{5}$.

The lumen may be widely patent in early childhood of life. The lumen is irregular due to presence of aggregated lymphoid follicle and bulges the mucous membrane and presence of multiple longitudinal folds of mucous membrane and usually admits a match stick. The lumen is open partially or wholly obliterated in the later decades of life because of decrease lymphoid follicle and the mucosa, the part of sub-mucosa replaced by fibrous connective tissue ${ }^{6}$.

The number of lymphoid follicles gradually increases to a peak of about 200, between the ages of 12 and 20 years. After 30 there is an abrupt reduction to less than half and then to a trace or total absence of lymphoid tissue after 60 years. Concurrent with lymphoid atrophy was fibrosis, which partially or totally obliterates the lumen in many older persons

In $60 \%$ cases, appendicitis are due to lymphoid hyperplasia leading to occlusion of the interior of the appendix, indicating that the appendix is usually prone to abnormal proliferation of its lymphoid tissue ${ }^{6}$.

Lymphocyte aggregation was first seen at the $17^{\text {th }}$ week of fetal period positive and meaningful correlation was found between gestational age and morphometric parameters of the vermiform appendix. A significant difference was found between the genders in the thickness of mucosa, which was larger in girls $(\mathrm{P}<0.05)$. When the proximal medium and distal parts were compared, the thickness of serosa between the proximal and distal parts was also significant different $(\mathrm{P}<0.005)$. The vermiform appendix matures in the second trimester during the fetal period. The morphologic development of the vermiform appendix is almost uniform from the proximal to distal parts. ${ }^{7}$ In the lymphatic follicle lymph is filtered, the nodes participate in localizing \& preventing the spread of infection into the general circulation $\&$ other organs ${ }^{8}$

In old age specially after $5^{\text {th }}$ decade, appendix gradually shrink, the lumen of the vermiform appendix almost fibrosed \& the lumen of vermiform appendix at birth and young age allows a match stick and remains irregular due to longitudinal mucosal folds. The lymphoid follicles are functioning by their antigen presenting cells. So here we can say appendix is not a vestigial organ, it is a secondary lymphoid organ and after functioning it becomes fibrosed in old age. ${ }^{8}$

There was no available literature regarding weight of vermiform appendix to compare with the present study. With these rationale in mind, present study was done to establish a Bangladeshi standard regarding weight of vermiform appendix which is essential for to say that appendix have important function for gut immunity.

\section{Conclusion}

Weight is the directly related with tissue mass of appendix. Here marked change found in old age especially after 5th decade mainly replacing lymphoid follicle by fibrous tissue. The weight of vermiform appendix decreased due to decrease in number, size of lymphatic follicle and their replacent by fibrous tissue. In young age, primary \& secondary follicles are present \& primary \& secondary immune response is high to any pathology in or near the vermiform appendix. In old age, weight is decreased due to decreased lymphoid tissue in vermiform appendix. 


\section{Article}

\section{Author Affiliations}

*1. Dr M Mahbubur Rahman, MBBS, M Phil, Curator of Anatomy, Mymensingh Medical College, Mymensingh - 2006, Bangladesh

2. Professor Dr Mohsin Khalil, MBBS, M Phil, Professor and Head of Anatomy, Mymensingh Medical College, Mymensingh - 2006, Bangladesh

3. Professor Dr Mansur Khalil, MBBS, M Phil, Ph D, DFM, Deputed to Centre for Medical Education, Mohakhali, Dhaka - 1212

4. Dr Mst Khurshida Jahan, MBBS, FCPS (Gynecology and Obstetrics), Resident Surgeon (Gynecology and Obstetrics), Mymensingh Medical College Hospital, Mymensingh - 2006, Bangladesh

5. Dr M Shafiquazzaman, MBBS, Clinical Pathologist, Mymensingh Medical College Hospital, Mymensingh - 2006, Bangladesh

6. Dr Bilkis Parvin, MBBS, Medical Officer, Pediatric out door, Mymensingh Medical College Hospital, Mymensingh - 2006, Bangladesh

* For correspondence

\section{References}

1. Borley NR. Editor, Microstructure of the large intestine. In: Berkovitz KBB, Borley NR, Crossman AR, Davis MS, Fitzgerald MJT, Glass J, et. al editors.
Mass of vermiform appendix

Grays Anatomy: The Anatomical Basis of Clinical Practice. 39 ${ }^{\text {th }}$ ed, Edinburgh: Elsevier Churchill Livingstone. 2005. p. 1173 - 86.

2. Bhide SA, Waderkar KV, Koushik SA. Peyer's patches are precocious to the appendix in human development. Department of Zoology, Nagpur, India. Dev Immunol. 2001; 8(2):159 - 66 .

3. Ross MH, Koye GI, Pawlina W, editors. Histology: A Text and Atlas, $5^{\text {th }}$ ed. Baltimore: Williams and Wilkins. 2005. p 528-74.

4. Schwartz SI, Principles of surgery, $7^{\text {th }}$ ed, McGraw Hill, International edition health profession Division. 1998. p. $1383-93$.

5. Lawrence WW, Doherty GM. Current Surgical Diagnosis and Treatment. $11^{\text {th }}$ ed. London: McGrawHill; 2003. p. $668-9$.

6. Datta AK. Essentials of Human Anatomy. Part - I. $6^{\text {th }}$ ed. Calcutta: Current books international. 2007. p. 228 -30 .

7. Malas MA, Sulak O, Gokcimen A. Development of the vermiform appendix during fetal period. Department of Anatomy, Suleyman Demirel University, Isparta, Turkey. Surg Radiol Anat. 2004 Jun; 26(3):202 - 7.

8. Eroschenko VP. di Fiore's Atlas of Histology. $7^{\text {th }}$ ed. Baltimore: Lippincott William and Wilkins; 2005. p. $215-7$. 